\title{
"Sou gay, sou alegre, mas não sou bagunça!": docência, homossexualidade e estética da existência
}

"I'm gay, I'm cheerful, but I'm not a mess!": teaching, homosexuality

and aesthetics of existence

Filipe Gabriel Ribeiro França*

Universidade Federal de Juiz de Fora

Resumo Este texto traz narrativas produzidas a partir de entrevistas narrativas com um professor homossexual durante uma pesquisa de mestrado. A questão analisada na pesquisa parte da seguinte inquietação: "Quais as narrativas, experiências e de que modos se constituem @s professor@s homossexuais?". Foi utilizado como referencial teórico-metodológico a perspectiva pós-estruturalista. A partir dessa perspectiva puderam ser problematizadas as formas pelas quais o professor pesquisado vai se constituindo enquanto docente homossexual e discutir como esse professor vai se produzindo nas relações de poder, nas relações com o outro e, sobretudo, como se relaciona com a instituição escolar. Assumir-se enquanto professor homossexual organiza a forma com que o sujeito se comporta dentro escola, vivenciando um contínuo processo de negociação com o outro e consigo mesmo.

PALAVRAS-CHAVE: Professor homossexual; Constituição docente; Escola.

Abstract This text brings narratives produced from interviews with a homosexual teacher for a master thesis. The question examined in the research of the following inquiry: "What are the narratives, experiences and modes that constitutes teachers gay?". Was used as theoretical and methodological framework poststructuralist perspective. From this perspective might be problematized the ways in which the teacher researched will constitute as gay teacher and discuss how this teacher will be producing power relations, in relations with each other and especially how it relates to the academic institution. Coming out as gay teacher organizes the way the subject behaves in school, experiencing an ongoing process of negotiation with each other and with themselves.

KEYWORDS: Gay teacher; Teaching constitution; School. 
Eu queria minha vida própria, por meu querer governada.

(ROSA, 2001, p. 445)

O desejo de Riobaldo, personagem principal do romance Grande Sertão: Veredas de João Guimarães Rosa, em querer "vida própria" e "governada" por si mesmo vai ao encontro do desejo de um $\mathrm{d}_{\mathrm{S}^{1}}$ professor@s homossexuais participantes de uma pesquisa. Vontades, coragem, descobertas, inquietações e experiências. Esses sentimentos surgem nas narrativas $\mathrm{d} @_{\mathrm{s}}$ professor@s ao falarem de suas vidas e compartilharem suas vivências.

Neste texto, invisto na discussão acerca das estéticas das existências e para tanto utilizo como inspiração as narrativas do professor Hermógenes ${ }^{2}$, professor dos anos iniciais do ensino fundamental da rede pública de ensino da cidade de Juiz de Fora-MG. As falas desse docente retratam momentos em que ele se constitui dentro da escola em que atua e vai assumindo a homossexualidade como um modo de vida.

Escrevo este texto influenciado pelas ideias e pelo referencial teórico-metodológico da perspectiva pós-estruturalista e pelas contribuições do filósofo francês Michel Foucault. Tal perspectiva me faz pensar nos modos como nos tornamos sujeitos e como nos constituímos em meio aos jogos de verdade. Provoca-me a problematizar as formas pelas quais o professor em questão vai se constituindo enquanto docente homossexual. Leva-me a discutir como esse professor vai se produzindo nas relações de poder, nas relações com o outro e, sobretudo, como se relaciona com a instituição escolar.

Nesse movimento de escrita, vou "aprendendo a operar com a provisoriedade, com o transitório, com o mutante. Isso está muito longe de significar que 'valetudo', mas implica praticar, frequentemente, o auto questionamento" (LOURO, 2004, p. 03-04). Essa perspectiva de pensamento me faz destacar as linguagens e os discursos, como práticas recheadas de relações de poder. Leva-me a preocupar mais com questões e interrogações do que com respostas. Assim, vou aprendendo a enxergar as verdades como construções históricas, movediças e momentâneas, verdades que são desconstruídas, produzidas e ressignificadas a todo o momento pelo professor Hermógenes.

Inspiro-me em Rago (2013) e abro a escrita a tudo aquilo que a prática acadêmica sempre resistiu, sem medo das emoções, das sensibilidades, das subjetividades e mesmo das dúvidas. Construo uma escrita comprometida com a verdade, mas não com a verdade positivista, que vê a linguagem como puro meio de comunicação. A verdade de que trato aqui é aquela à qual Foucault se referia ao reviver o conceito antigo de parrhesía, o dizer a verdade sem medo, uma verdade eminentemente política, que fere e provoca.

$\mathrm{Na}$ tentativa de imergir no campo e buscar informações para serem problematizadas, utilizei como estratégia de pesquisa a entrevista narrativa, compreendendo que o caminho metodológico

é o de alquimia mesmo, resultando daí uma bricolagem diferenciada, estratégica e subvertedora das misturas homogêneas típicas da 
modernidade. Alquimia que rompe com as orientações metodológicas formalizadas na e pela academia (particularmente nos cursos de pós-graduação), cuja direção costuma ser a das abordagens classificatórias, $[. .$.$] em que cada método vem apresentado em estado puro.$ (CORAZZA, 2007, p. 118).

Entendo que a composição metodológica adotada por mim não é nova, já foi inúmeras vezes utilizada. Porém, encarei as entrevistas com o professor não apenas como um conjunto de falas isoladas, mas como narrativas de si desse sujeito, pois narrar um fato não é apenas relatar ou viver o que já passou, "implica um certo sentido do que somos" (LARROSA, 2002b, p. 68) para esse professor e para mim.

Por meio das narrativas, o professor dá um novo significado ao que já viveu e ao seu presente, fazendo uso das palavras para descrever quem ele é, quais experiências o marcaram, o que pensa, o que sente e como vive. Pensando com Larrosa, quando nos envolvemos com as palavras "damos sentido ao que somos e ao que nos acontece, de como correlacionamos as palavras e as coisas, de como nomeamos o que vemos ou o que sentimos e de como vemos ou sentimos o que nomeamos" (2002a, p. 21).

Nós, seres humanos somos contadores de histórias, sujeitos que, individual e socialmente, vivemos e nos relacionamos com vidas relatadas. Trabalhar com as narrativas é, portanto, estudar as formas como os sujeitos experienciam o mundo. As narrativas e a vida vão caminhando juntas e, portanto, o atrativo principal da narrativa como estratégia metodológica é sua capacidade de conduzir os sujeitos a reproduzirem as suas experiências da vida, de forma relevante e cheia de sentido. Assim como Foucault (2012b, p. 21), "suponho, mas sem ter muita certeza, que não há sociedade onde não existam narrativas maiores que se contam, se repetem e se fazem variar". Narrativas recheadas de "fórmulas, textos, conjuntos ritualizados de discursos que se narram, conforme circunstâncias bem determinadas; coisas ditas uma vez e que se conservam, porque nelas se imagina haver algo como um segredo ou uma riqueza" (idem).

Deste modo, a narrativa constitui-se como uma modalidade discursiva, na qual as histórias que contamos e as histórias que ouvimos, produzidas e mediadas no interior de determinadas práticas sociais, passam a construir a nossa história, a dar sentido a quem somos e a quem são os outros, constituindo assim as nossas identidades - de gênero, sexual, racial, religiosa, de professor/a, de classe social, de mãe e pai, filh@, entre outras. Assim, construímos e expressamos a nossa subjetividade a partir das formas linguísticas e discursivas que empregamos nas nossas narrativas (RIBEIRO, SOARES e FERNANDES, 2009).

Acredito que "as entrevistas não permitem dizer uma ou $a$ verdade sobre as coisas e os fatos, mas pode-se considerá-las como a instância central que, somada a outras, traz informações fundamentais acerca do vivido e possibilita uma interpretação" (ANDRADE, 2012, p. 175), mesmo que provisória e parcial, das vivências dos sujeitos na escola. Sendo assim, faço a exploração das narrativas, buscando problematizar as construções históricas, sociais e culturais que conduzem a constituição dos discursos e dos sujeitos. Isso implica em 
escapar da fácil interpretação daquilo que está "por trás” dos documentos, procurando explorar ao máximo os materiais, na medida em que eles são uma produção histórica, política; na medida em que as palavras são também construções; na medida em que a linguagem é também constitutiva de práticas. (FISCHER, 2001, p. 199).

O que essas narrativas podem produzir? Penso que "pelas narrativas, histórias são escritas e identidades são discursivamente produzidas" (ANDRADE, 2012, p. 180), proporcionando a construção de um texto que se caracterize pelo encontro de múltiplas vozes, de diferentes lugares, contextos sociais e culturais. "As informações que são coletadas em um trabalho de campo não são dados passíveis de serem explicados, mas são significados produzidos no contexto pesquisado, que podem ser lidos e construídos de diferentes formas"(REIS, 2012, p. 247). Essas informações contribuem para o processo de análise discursiva do material coletado nas entrevistas narrativas.

No decorrer desta travessia não pretendi e nem desejei produzir certezas e/ ou verdades, pelo contrário, quis que elas fossem problematizadas, colocadas em questão, discutidas, abaladas e desmanchadas!

\title{
Estéticas da existência, artes de viver!
}

Gay, viado, homossexual... Palavras constantes nas falas do professor Hermógenes. Palavras que dizem do seu modo e estilo de vida. Palavras que carregam vida! Possibilidades de viver a vida! A vida como um instigante, provocante e apaixonante conjunto de "artes da existência". Foucault nos fala que

\begin{abstract}
estas devem ser entendidas como as práticas racionais e voluntárias pelas quais os homens não apenas determinam para si mesmos regras de conduta, como também buscam transformar-se, modificarse em seu ser singular, e fazer de sua vida uma obra que seja portadora de certos valores estéticos e que corresponda a certos critérios de estilo. (2012b, p. 193).
\end{abstract}

Neste sentido, a estética da existência tem "compromisso com mudanças que levam à criação de novos estilos de vida baseados em uma ética capaz de criar subjetividades mais libertárias e, a partir delas, novas formas de sociabilidade" (MISKOLCI, 2006, p. 689). Com o conceito foucaultiano de estética da existência abre-se a possibilidade de invenção de novas formas de se viver e de afetividade entre os sujeitos. Portanto, a noção de estética da existência propicia a emergência da "discussão e questionamento de padrões normalizadores, heterônomos e identitários, que formatam o indivíduo contemporâneo ao aprisioná-lo em rígidas identidades previamente definidas" (CÉSAR, DUARTE, SIERRA, 2013, p. 75). A criação de novas formas de sociabilidade também se dá no exercício da profissão docente e nas relações que os sujeitos estabelecem com a instituição escolar. O professor Hermógenes cria seu próprio estilo de vida e vai construindo a sua identidade na escola:

Eu desmunheco na hora que eu quero. Desmunheco na sala dos professores, dou pinta, subo em cima da mesa, faço show de gogoboy. $\mathrm{Na}$ reunião de professores eu sempre coloco: 'vocês acham que pelo fato de eu ser viado o negócio aqui é só bagunça?’. Sou gay, sou alegre, mas não sou bagunça! [...] Tudo está relacionado com o 
comprometimento com o trabalho. Você ser comprometido com o trabalho é que faz a diferença. (Professor Hermógenes).

Ele busca enfatizar que o fato de se expressar no ambiente escolar de uma maneira que escapa do que se espera de um professor não significa que ele não leve o seu trabalho a sério: "Sou gay, sou alegre, mas não sou bagunça!". O professor Hermógenes procura destacar que apesar de ser gay e alegre ele não é bagunça, deixando escapar a visão que ele e parte da sociedade têm sobre a homossexualidade masculina, numa tentativa de conquistar respeito e confiança junto aos/às seus/suas colegas de trabalho. Assim, ele revela um saber sobre a escola e sobre a profissão docente como lugares de seriedade e responsabilidade. Mas também revela o lugar da homossexualidade (pelo menos no senso comum) como um lugar de bagunça e descomprometimento.

Ao dizer que "tudo está relacionado com o comprometimento com o trabalho. Você ser comprometido com o trabalho é que faz a diferença", existe uma preocupação do professor Hermógenes em afirmar que realizar um bom trabalho independe da identidade sexual. Tem outra posição de sujeito ou identidade em negociação. Existe um jogo entre as identidades normalizadas e as marginalizadas. De certa forma, o professor reivindica a identidade híbrida, fazendo dialogar o "ser professor" com o "ser gay".

Assim, o seu estilo de vida é construído durante a docência, ou seja, a constituição de si também passa pelo ambiente escolar. $\mathrm{Na}$ escola ele se cria, socializa e se produz: "Eu desmunbeco na hora que eu quero. Desmunbeco na sala dos professores, dou pinta, subo em cima da mesa, faço show de gogoboy". Nessa sua ação de constituir-se, ele nos mostra "efetivamente que não há um sujeito soberano, fundador, uma forma universal de sujeito que poderíamos encontrar em todos os lugares" (FOUCAULT, 2012a, p. 284), ou seja, existem múltiplas possibilidades de existirmos no mundo e o professor Hermógenes vai criando, dia a dia, sua existência dentro da escola, pois, "aprender-aviver é que é o viver, mesmo" (ROSA, 2001, p. 722).

É importante destacar que a criação de novos estilos de vida não remete apenas ao exercício e vivência de sexualidades não-hegemônicas. A proposta de uma estética da existência está intimamente ligada à transgressão da heteronormatividade, um rompimento com padrões sociais e identitários que aprisionam os sujeitos em uma única forma de manifestação afetivo-sexual. Sendo assim, ser professor declaradamente homossexual na escola possui as suas implicações:

Se você é gay as pessoas acham que você tem que ser cheio de trejeitos e eu já não acho isso. Eu tenho o meu lado profissional, o professor, de não deixar de contar uma piada, que não deixa de dar uma desmunhecada dentro da sala de aula, mas também eu vejo que não existe essa separação. Quantas vezes em reunião eu já peguei um salto, falava 'eu ando bem nisso, vocês nem imaginam' e desfilava pela sala. (Professor Hermógenes).

O professor assume a junção da identidade homossexual com a identidade docente, afirmando que "não existe essa separação" entre as duas identidades, ao mesmo tempo em que destaca o olhar estereotipado da sociedade sobre a homossexualidade: "Se você é gay as pessoas acham que você tem que ser cheio de trejeitos e eu já não acho isso". Esse movimento nos conduz a pensar em como a emergência de uma cultura de si 
pode desencadear relações críticas aos modelos de identidades que nos cercam e que nos são propostos, abrindo a possibilidade de recusa frente aos investimentos disciplinares que nos tornam carrascos de nós mesmos. Assim, o "sujeito se constitui através das práticas de sujeição ou, de maneira mais autônoma, através de práticas de liberação, de liberdade", práticas que consistem em "um certo número de regras, de estilos, de convenções que podemos encontrar no meio cultural" (FOUCAULT, 2012a, p. 284). As identidades, o que somos e o que nos tornamos saem desse jogo entre o social e o individual.

Ao nos reinventarmos também podemos nos permitir novas relações com o outro, relações que se constituem em companheirismo e amizade. Desta forma, podemos perceber que os nossos processos de subjetivação não são processos individualistas, eles se dão nas relações que estabelecemos com o outro porque "para que a prática de si alcance o eu por ela visado, o outro é indispensável” (FOUCAULT, 2010, p. 115). O professor Hermógenes narra alguns momentos dessas relações com o outro que são estabelecidas em seu ambiente de trabalho:

\begin{abstract}
Há muitas conversas entre os professores e eu para o esclarecimento disso, o que é um ativo, o que é um passivo, o que é um transgênero, o que é urso. Eles vem tirar dúvidas comigo, eu viro uma referência nessa questão. Se tinha realmente aquela questão preconceituosa, do viado, do gay, do homossexual, eu acredito que a minha atuação, a minha presença, o meu comportamento, tem operado para desconfigurar essa coisa do viado, de que o viado é travesti, de que todo viado é um travesti, é uma bichinha que gosta de ficar desmunhecando. Eu acredito que o meu comportamento, a minha postura, a minha configuração de vida tenha contribuído para desmistificar muita coisa na questão da aceitação de dois homens estarem vivendo juntos. (Professor Hermógenes).
\end{abstract}

As relações criadas entre o professor Hermógenes e @ demais professor@ possibilitam que exista um clima de liberdade que faz com que a curiosidade sobre as vivências homossexuais venha à tona: "Há muitas conversas entre os professores e eu para o esclarecimento disso, o que é um ativo, o que é um passivo, o que é um transgênero, o que é urso. Eles vem tirar dúvidas comigo, eu viro uma referência nessa questão". Ser homossexual, na visão de seus/suas colegas professor@s, parece garantir automaticamente ao professor Hermógenes todo um conhecimento específico sobre as homossexualidades e suas práticas, chegando ao ponto dele se tornar "referência nessa questão". Esse conhecimento da "experiência" que o professor possui desperta o interesse dos outros e os outros também se constituem nessas relações, ou seja, a heterossexualidade também está sendo construída no encontro com a homossexualidade. Ao tornar-se referência e exemplo de homossexual para a comunidade escolar, ele trabalha na perspectiva de desconstruir o estereótipo de homossexualidade presente naquela escola "de que todo viado é um travesti, é uma bichinha que gosta de ficar desmunhecando", porque "a estética da existência só é possível como devir, quando desconstrói as representações sociais que criam e impõem identidades” (MISKOLCI, 2006, p. 690). Assim, não dá para falar em homossexualidade no singular, mas sim no plural. A sua presença naquele ambiente acaba estimulando a compreensão acerca das diferentes formas de viver as sexualidades para além da heterossexualidade: "Eu acredito que o meu comportamento, a 
minha postura, a minha configuração de vida tenha contribuído para desmistificar muita coisa na questão da aceitação de dois homens estarem vivendo juntos". Deste modo, a sua postura exerce uma ação sobre o outro.

A constituição de novas relações para consigo e para com os outros é uma manifestação de resistência que exige do sujeito um esforço que resulta no desprendimento e desenraizamento das oposições binárias que o cercam. Homossexualidade e heterossexualidade estão atravessadas por relações de poder. Ao colocar a homossexualidade no centro, o professor resiste. A resistência constitui-se enquanto uma experiência de subjetivação e de experimentação da liberdade. Resistir é um combate. Uma luta com as adversidades. Resistência é um sinal de liberdade, prova de que é possível escapar dos enquadramentos propostos pelas forças. Ela demonstra que existe espaço para mudanças, oscilações e inversões nas relações de poder. Essas estratégias são dirigidas contra as formas de sujeição e submissão, remetendo ao conceito de liberdade e a sua ligação à insatisfação em uma determinada relação. Tenho pensado que a "liberdade é da ordem dos ensaios, das experiências, dos inventos, tentados pelos próprios sujeitos que, tomando a si mesmos como prova, inventarão seus próprios destinos" (SOUSA FILHO, 2011, p. 16). Deste modo, o professor Hermógenes vai criando seus próprios modos de existência, fazendo da sua vida uma constante rede de experiências, em que as experiências de liberdade não podem ser tratadas como algo definitivo, pois, elas estão sempre sujeitas a mudanças e transformações, tal como o

vento que vem de toda parte. Dando no meu corpo, aquele ar me falou em gritos de liberdade. Mas liberdade - aposto - ainda é só alegria de um pobre caminhozinho, no dentro do ferro de grandes prisões. Tem uma verdade que se carece de aprender, do encoberto, e que ninguém não ensina: o bêco para a liberdade se fazer. (ROSA, 2001, p. 388).

Os corpos hoje agem com certa liberdade para romperem as fronteiras morais vigentes, levando os sujeitos a se transformarem, estilizando a sua existência, assim como tem feito o professor Hermógenes na escola em que atua.

A autonomia sobre a sua própria existência permite que o sujeito reconheça que os prazeres de viver estão sempre abertos a redefinições e reconstruções. Nesse sentido, as relações de poder atuam nos processos de fabricação de nossos corpos, sexualidades, prazeres e subjetividades. Essas subjetividades recebem o complemento da intersubjetividade como forma de governo de si e de seu corpo, conectadas com as relações estabelecidas com o outro. A fala desempenha um papel de destaque, pois o ato de falar pressupõe-se um ouvir e compreender, num processo em que ao ouvir o outro acabo me constituindo junto a ele a partir de sua fala. Ortega (1999, p. 126) nos lembra que "a constituição do indivíduo como sujeito ético efetua-se só por meio de relações complexas com o outro (cujo estatuto e formas são diferentes segundo a época). O outro é indispensável na cultura de si”, ou seja, o outro está sempre presente na origem da nossa constituição estética. Estética como investimento em outras formas de vida. Ao compartilharmos práticas com o outro, somos remetidos ao contexto intersubjetivo que nos proporciona esse encontro com ele, pensando que a experiência também surge e é produzida a partir de um mundo compartilhado. 
Nesse compartilhamento, creio que um dos objetivos seja fazer do corpo um lugar de experienciação ${ }^{3}$, autonomia e de produção de prazeres. Um corpo que é produto de um poder disciplinar e de uma biopolítica que o atravessa e o constitui. O sujeito pode mergulhar em uma pluralidade de campos; ele será o arquiteto de uma rede, o iniciador de suas relações sociais em um universo construído por ele mesmo para si mesmo (ORTEGA, 1999). Já dizia Guimarães Rosa: "O correr da vida embrulha tudo, a vida é assim: esquenta e esfria, aperta e daí afrouxa, sossega e depois desinquieta. O que ela quer da gente é coragem" (2001, p. 402). Coragem de viver, de experienciar, de arriscar, de ousar, de construir a vida enquanto uma obra de arte.

Penso que o importante é o modo como se vive, investindo numa existência cheia de possibilidades, onde experienciar a multiplicidade torna-se uma forma de vida possível. E nessa multiplicidade existências e sujeitos são criados, fabricados, construídos, reconstruídos, marcados, atravessados e vividos. Os sujeitos não se cansam e não param de construir a si mesmos. Como Riobaldo, personagem criado por Guimarães Rosa, ainda me admiro, viajo e me animo com a boniteza do inacabamento humano:

O senhor... Mire veja: o mais importante e bonito, do mundo, é isto: que as pessoas não estão sempre iguais, ainda não foram terminadas - mas que elas vão sempre mudando. Afinam ou desafinam. Verdade maior. É o que a vida me ensinou. Isso que me alegra montão. (ROSA, 2001, p. 48).

\section{Algumas considerações longe de serem finais...}

A temática que trouxe para discussão neste texto possui uma questão central: a constituição da homossexualidade na escola. Ao problematizar as estéticas da existência, quis mostrar como as homossexualidades vão se constituindo e como a escola é um espaço importante para essa constituição.

Ao longo de suas narrativas o professor Hermógenes denuncia que está imerso em jogos de verdades e subjetividades, "jogos do verdadeiro e do falso através dos quais o ser se constitui historicamente como experiência, ou seja, como podendo e devendo ser pensado" (FOUCAULT, 2012b, p. 190). Assim, ele revela que está em um mundo organizado, um mundo que tem os seus saberes sobre as homossexualidades, sobre o que é ser professor/a e sobre a escola. Esses saberes estabelecem a forma como ele lida consigo mesmo e com os lugares que ocupa. Tal organização expõe uma homossexualidade que é sempre racionalizada, fazendo com que o professor pense nas maneiras como ele se comporta e como age nas salas de aula. Dessa forma, a homossexualidade passa a exigir uma racionalidade de si, um incômodo, um pensar e um inquietar-se consigo mesmo. Assim, o sujeito se vê vivenciando uma experiência de (des)subjetivação a partir de suas inserções nos jogos de verdade, nas relações de poder e nas formas de relação consigo mesmo e com os outros.

\section{Referências}

ANDRADE, S. S. A entrevista narrativa ressignificada nas pesquisas educacionais pós-estruturalistas. In: MEYER, D. E.; PARAÍSO, M. A. (Organizadoras). Metodologias de pesquisas pós-críticas em educação. Belo Horizonte, Mazza Edições, 2012, p. 173-194. 
CÉSAR, M. R. A.; DUARTE, A. M.; SIERRA, J. C. A estética da existência e as artes de viver: Michel Foucault e a crítica da noção de sujeito nos movimentos feministas, LGBT e na educação. In: CLARETO, S. M.; FERRARI, A. (Orgs.). Foucault, Deleuze e Educação. 2a edição ampliada e revisada. Juiz de Fora: Ed. UFJF, 2013, p. 63-80.

CORAZZA, S. M. Labirintos da pesquisa, diante dos ferroulhos. In: COSTA, M. V. (Organizadora). Caminhos investigativos I: novos olhares na pesquisa em educação. $3^{a}$ ed. Rio de Janeiro: Lamparina, 2007, p. 103-127.

FISCHER, R. M. B. Foucault e a análise do discurso em educação. Cadernos de Pesquisa, no 114, p. 197-223, novembro de 2001. Disponível em: <http://www.scielo.br/pdf/cp/n114/ a09n114.pdf> Acesso em: 10 fev. 2013.

FOUCAULT, M. A hermenêutica do sujeito: curso dado no Collège de France (1981-1982). Edição estabelecida sob a direção de Francois Ewald e Alessandro Fontana, por Frédéric Gros. Tradução: Márcio Alves da Fonseca e Salma Annus Muchail. $3^{a}$ Ed. São Paulo: WMF Martins Fontes, 2010

FOUCAULT, M. Uma estética da existência. In: MOTTA, M. B. (organização, seleção de textos e revisão técnica). Ditos e Escritos, volume V: Ética, sexualidade, política. Tradução: Elisa Monteiro, Inês Autran Dourado Barbosa. 3a Ed. Rio de Janeiro: Forense Universitária, 2012a, p. 281-286.

FOUCAULT, M. O uso dos prazeres e as técnicas de si. In: MOTTA, M. B. (organização, seleção de textos e revisão técnica). Ditos e Escritos, volume V: Ética, sexualidade, política. Tradução: Elisa Monteiro, Inês Autran Dourado Barbosa. $3^{a}$ Ed. Rio de Janeiro: Forense Universitária, 2012b, p. 187-211

LARROSA, J. Notas sobre a experiência e o saber de experiência. Revista Brasileira de Educação. 2002a, no 19, p. 20-28. ISSN 1413-2478. Disponível em: <http://www.anped.org.br/ rbe/rbedigital/RBDE19/RBDE19_04_JORGE_LARROSA_BONDIA.pdf> Acesso em: 26 jul. 2012.

LARROSA, J. Tecnologias do eu e educação. In: SILVA, T. T. (Org.). O sujeito da educação: estudos foucaultianos. $5^{\text {a }}$ ed. Petrópolis: Vozes, 2002b, p. 35-86.

LOURO, G. L. Conhecer, pesquisar, escrever... In: V Anped Sul, 2004. Disponível em: <http:// www.portalanpedsul.com.br/admin/uploads/2004/Painel/Painel/12_11_02_CONHECER, PESQUISAR,_ESCREVER.pdf>. Acesso em: 10 fev. 2013.

MISKOLCI, R. Corpos elétricos: do assujeitamento à estética da existência. Estudos Feministas, Florianópolis, 14(3), p. 681-693, setembro-dezembro/2006. Disponível em: <http://www. scielo.br/pdf/ref/v14n3/a06v14n3.pdf> Acesso em: 28 dez. 2012.

ORTEGA, F. Amizade e estética da existência em Foucault. Rio de Janeiro: Graal, 1999.

RAGO, M. A aventura de contar-se - feminismos, escrita de si e invenções da subjetividade. Campinas: Ed. Unicamp, 2013.

REIS, C. Á. O uso da metodologia queer em pesquisa no campo do currículo. In: MEYER, D. E.; PARAÍSO, M. A. (Organizadoras). Metodologias de pesquisas pós-críticas em educação. Belo Horizonte, Mazza Edições, 2012, p. 243-260.

RIBEIRO, P. R. C.; SOARES, G. F.; FERNANDES, F. B. M. A ambientação de professores e professoras homossexuais no espaço escolar. In: JUNQUEIRA, R. D. Diversidade Sexual na Educação: problematizações sobre a homofobia nas escolas. Brasília: Ministério da Educação, Secretaria de Educação Continuada, Alfabetização e Diversidade, UNESCO, 2009, p. 183-211.

ROSA, J. G. Grande sertão: veredas. 20ª ed. Rio de Janeiro: Nova Fronteira, 2001. 
SOUSA FILHO, A. Foucault: o cuidado de si e a liberdade ou a liberdade é uma agonística. In: ALBUQUERQUE JÚNIOR, D. M.; VEIGA-NETO, A.; SOUSA FILHO, A. (Organizadores). Cartografias de Foucault. 2a Ed. Belo Horizonte: Autêntica, 2011, p. 13-26.

\section{Notas}

${ }^{1}$ Utilizo o caractere @ na tentativa de contemplar todos os gêneros durante a escrita.

${ }^{2}$ Nome fictício. Hermógenes é um dos personagens do romance "Grande Sertão: Veredas" de autoria de João Guimarães Rosa.

${ }^{3}$ Assumo o termo experienciar como referência às experiências que tocam, atravessam e transformam os sujeitos. Um termo que se distancia do ato de experimentar, que remete à palavra experimento, como algo que se quer por à prova.

* Doutorando em Educação pela Universidade Federal de Juiz de Fora, Juiz de Fora, Minas Gerais, Brasil.

\section{Correspondência}

Filipe Gabriel Ribeiro França - Universidade Federal de Juiz de Fora, Faculdade de Educação. Rua José Lourenço Kelmer, s/n, São Pedro, CEP: 36036-900 - Juiz de Fora, Minas Gerais - Brasil.

E-mail: filipe.gfranca@yahoo.com.br

Recebido em 04 de março de 2015

Aprovado em 11 de março de 2016 